\title{
Nihil silentio utilius: confidentiality in mediation and its legal safeguards in the EU Member States
}

\author{
Rafal Morek
}

Published online: 1 October 2013

(C) The Author(s) 2013. This article is published with open access at Springerlink.com

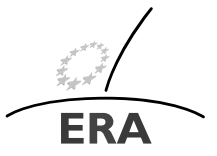

EUROPÄISCHE RECHTSAKADEMIE ACADEMY OF EUROPEAN LAW ACADEMIE DE DROIT EUROPEEN ACCADEMIA DI DIRITTO EUROPEO TRIER - TREVES - TREVIRI

\begin{abstract}
While mediation is all about communication, its boundaries-in many respects - need to be established. Confidentiality is at the heart of the mediation process. It encourages parties to mediation to speak freely and openly. It is essential for the success of mediation both in individual cases and as an institution-a popular dispute resolution method alternative to litigation. This article adopts a particular focus on the confidentiality-related regulations and problems in the EU law and its Member States. While the vast majority of European countries have complied with the 2008 EU Mediation Directive, its requirements may be viewed as insufficient. Article 7 of the Directive provides for a minimum degree of compatibility and very basic standards only. While the current regulations in the Member States differ vastly, so do the consequences of a breach of the duty and a leak of confidential information. This leads to uncertainty and accidental results in cross-border mediations within the EU. Such a situation is unsatisfactory and is even made worse by the fact that the Directive allows member states to decide freely on the qualifications, requirements and other regulations applicable to mediators. Therefore the article calls for further harmonization to establish higher standards and greater clarity.
\end{abstract}

Keywords Mediation - Conciliation - Dispute resolution · Mediator · Confidentiality $\cdot$ Secrecy $\cdot$ Privilege $\cdot$ Evidentiary restrictions $\cdot$ Harmonization

The Latin inscription "Nihil silentio utilius" is sometime incorrectly translated as "Silence is useless". Its actual meaning is quite the opposite- "Nothing [is] more useful than silence".

Dr. R. Morek, Assistant Professor, Advocate, Mediator ( $\square)$

University of Warsaw, K\&L Gates LLP, Warsaw, Poland

e-mail: rafal.morek@klgates.com 


\section{Introduction}

The proverb "Reden ist Silber, Schweigen is Gold" (Speech is silver, silence is golden) fits well into the context of mediation. While mediation is all about communication, its boundaries - in many respects — need to be established. Confidentiality is at the heart of the mediation process. It encourages parties to mediation to speak freely and openly. This is because they must not fear (or at least fear much less) that their words may be used against them when revealed to an outsider to the mediation process, such as a judge in a court or a market competitor.

Confidentiality is essential for the success of mediation both in individual cases and as an institution - a popular dispute resolution method alternative to litigation. ${ }^{1}$ While state court proceedings are in principle open to the public in most jurisdictions, the rule of mediation is opposite. It is a private procedure by nature. And its private character encompasses, among other things, confidentiality and secrecy. Confidentiality is therefore considered a key principle of mediation, or even an essential part of its definition. ${ }^{2}$

Empirical studies show that the confidentiality of the mediation process is valued by its users. ${ }^{3}$ It has also been became "the centerpiece of conciliation [mediation] regime", ${ }^{4}$ including both modern mediation laws and mediation rules, as well as norms other than legal, such as codes of conduct or mediator's ethics. ${ }^{5}$ On the other hand, from a global transnational and intercultural perspective, the confidentiality principle may be seen as a mere Western concept. In some other legal traditions, it is a usual routine that community members may not only be observers, but also active stakeholders taking part in the dispute resolution processes. ${ }^{6}$

This article adopts a particular focus on the confidentiality-related regulations and problems in the EU law and its Member States. While the vast majority of European countries have complied with the 2008 Directive, its requirements may be viewed as

\footnotetext{
${ }^{1}$ While the above opinion is shared by the majority of authors and practicing mediators, it is sometimes challenged. For example, according to J. Reich, there is no sufficient empirical evidence indicating that confidentiality is necessary for the success of the mediation process. He also suggested that statutory provisions on confidentiality do not influence parties' conduct in mediation in any significant way, as they are rarely aware of such regulations and their implications-Reich [18]. See also Green [10], p. 2 et sub.; Hughes [12]; Goldberg, Sander, Rogers [9], p. 442 (noting that "[l]awmakers have little evidence to guide them in assessing whether assurance of confidentiality is necessary to promote the frank discussion necessary to achieve settlement.").

${ }^{2}$ See e.g. the legal definition of mediation in Article 2 of the Bulgarian Mediation Law (State Gazette No. 110/17.12.2004, amended and supplemented, SG No. 86/24.10.2006, supplemented, SG No. 9/28.01.2011, amended and supplemented, SG No. 27/1.04.2011): "Mediation is a voluntary and confidential procedure for out-of-court resolution of disputes, whereby a third party mediator assists the disputants in reaching a settlement".

${ }^{3}$ See e.g. the survey results in the report "Mediation: Through the Eyes of New York Litigators. Report of the Mediation Committee of the New York State Bar Association Dispute Resolution Section and The Alternative Dispute Resolution Committee of the New York City Bar Association" (2011), www.nysba.org.

${ }^{4}$ Sekolec, Getty [20], p. 189.

${ }^{5}$ See e.g. European Code of Conduct for Mediators, points 3.1 and 4.

${ }^{6}$ See e.g. Ury [21], p. 5; Antaki [2].
} 
insufficient. Article 7 of the EU Directive provides for a minimum degree of compatibility and very basic standards only. ${ }^{7}$ While the current regulations in the Member States differ vastly, so do the consequences of a breach of the duty and a leak of confidential information. This leads to uncertainty and accidental results in cross-border mediations within the EU. Such a situation is unsatisfactory and is even made worse by the fact that the Directive allows member states to decide freely on the qualifications, requirements and other regulations applicable to mediators. ${ }^{8}$ Therefore the article calls for further harmonization to establish higher standards and greater clarity.

\section{Purposes and functions of the principle of confidentiality in mediation}

Before exploring more specific issues, one should ask the question as to why confidentiality in mediation actually matters. What do we protect when seeking to assure "confidentiality" in mediation? What in this respect, if anything, deserves legal or other protection?

The EU Directive does not answer the above questions. It just states in its Preamble that "confidentiality in the mediation process is important and this Directive should therefore provide for a minimum degree of compatibility of civil procedural rules with regard to how to protect the confidentiality of mediation in any subsequent civil and commercial judicial proceedings or arbitration" (Recital 23). ${ }^{9}$

Beyond the Directive, the 2002 UNCITRAL Model Law on International Commercial Conciliation has been seen as a set of universal (global) standards for mediation regulations. Even if the Model Law had not become a huge success in terms of the number of jurisdictions where it was adopted, ${ }^{10}$ it remains a key point of reference for drafters of mediation laws. It is indisputable that no other juridical instrument exists with a comprehensive set of mediation rules adopted under the aegis of the United Nations or any other organization with a global reach.

\footnotetext{
${ }^{7}$ This results explicitly from the Directive itself, which describes its regulation in Article 7(1) by referring to "a minimum degree of compatibility" (Recital 23), and declares in Article 7(2) that "nothing in paragraph 1 shall preclude Member States from enacting stricter measures to protect the confidentiality of mediation."

${ }^{8}$ Those two issues, i.e. safeguards of confidentiality and the legal and professional status of a mediator, are closely interrelated. The link is relevant, among other things, in the context of liability for a mediator's breach of confidentiality duty as well as the parties' trust that confidentiality will be respected. As set out in the Directive's Preamble (Recital 16): "To ensure the necessary mutual trust with respect to confidentiality (...), Member States should encourage, by any means they consider appropriate, the training of mediators and the introduction of effective quality control mechanisms concerning the provision of mediation services."

${ }^{9}$ According to the Green Paper released by the European Commission in 2004: "[c]onfidentiality appears to be the key to the success of ADR because it helps guarantee the frankness of the parties and the sincerity of the communications exchanged in the course of the procedure"-Green Paper on Alternative Dispute Resolution in Civil and Commercial Law, COM/2002/0196 final, p. 29.

${ }^{10}$ According to the UNCITRAL Secretariat, legislation based on the Model Law has been adopted in the following jurisdictions: Albania (2011), Belgium (2005), the Canadian provinces of Nova Scotia (2005) and Ontario (2010), Croatia (2003), France (2011), Honduras (2000), Hungary (2002), Luxembourg (2012), Montenegro (2005), Nicaragua (2005), Slovenia (2008), Switzerland (2008), The former Yugoslav Republic of Macedonia (2009) and in twelve states in the US.
} 
The Official Guide to UNCITRAL Model Law identifies the goals that led its drafters. One of them is "to promote frank and open discussions of parties by ensuring confidentiality of the process, limiting disclosure of certain information and facts raised in the conciliation in other subsequent proceedings subject only to the need for disclosure required by law or for the purposes of implementation or enforcement". ${ }^{11}$

The promotion of open communication has also been a leitmotiv in numerous publications on the subject matter. It is argued that without the adequate safeguards of confidentiality, parties to a dispute would be reluctant to disclose information needed to find a settlement. No shrewd party or attorney would present information that could later be used against him at trial. As a result, many valuable opportunities (including those related to outcomes of the process, as well as time, cost, reputation, relationship, etc.) offered by mediation would be lost. Frank and open discussion is a cornerstone on which a mediator may assist parties to make a "shift from positions to interests" and engage them in a conversation on a whole range of possible solutions to their dispute. It is also essential to rationality in negotiations. ${ }^{12}$

All those advantages would be frustrated if the parties had to fear that information disclosed in mediation could be used to their prejudice in subsequent legal proceedings. The parties would less willing to consider different options if they fear that their proposals may be taken as a concession and held against them in litigation or arbitration. Mediation conducted without confidentiality protections could also be abused as a self-standing process. To quote $N$. Alexander: it would "invite fishing expeditions with good catches to be made by opportunistic negotiators at the expense of vulnerable parties such as those that are unrepresented". ${ }^{13}$ Hence confidentiality, if solidly protected, should increase the parties' willingness to engage in mediation.

Confidentiality is also said to enhance the effectiveness of dispute resolution in other ways. It is related to the informal nature of mediation, which avoids much of the time and costs that would be involved in formal documentation, necessary to allow for appellate or other similar procedures. Confidentiality is linked with limited grounds of judicial review of mediated settlements and the mediation process as such. Therefore, as noted by N. Alexander, "confidentiality of the mediation process (...) affords it a considerable level of procedural finality, even if no settlement is reached". 14

\section{Dimensions of confidentiality in mediation}

What does confidentiality of mediation actually mean? Confidentiality is a multifaceted concept. From the structural perspective its internal (among mediation participants) and external (vis-à-vis third parties) dimensions can be distinguished.

\footnotetext{
${ }^{11}$ Official Guide to UNCITRAL Model Law, General principles upon which the Model Law is based, p. 41.

${ }^{12}$ Brazil [3].

${ }^{13}$ Alexander [1], p. 246.

${ }^{14}$ Ibidem.
} 
The internal dimension regulates flows of information within mediation. It becomes relevant when a mediator uses caucusing, i.e. private sessions with individual parties. A mediator can manage the "internal confidentiality" in one of two ways: by adopting the "open communication" approach or the "in-confidence" approach. ${ }^{15}$ The former assumes that no information is confidential to the other participants in mediation, unless specifically restricted by the relevant parties. The latter operates in a converse manner by treating all information disclosed privately as confidential unless the disclosing party indicates otherwise. Each model has its pros and cons. ${ }^{16}$ While there are no grounds to find any of them inadmissible, it is essential for the integrity of the mediation process that a mediator declare explicitly which model is to be applied in a given case.

The external dimension relates to confidentiality towards third parties, i.e. "outsiders" to the mediation process. It forbids the participants from disclosing information from the mediation to non-participants, unless a given disclosure is permitted under subjective or objective exceptions to the confidentiality principle. ${ }^{17}$ A specific subcategory of the external dimension of confidentiality relates to a court or an arbitral tribunal, and the disclosing of the information from the mediation in a subsequent litigation or arbitration proceeding.

The distinction between the internal and external dimensions of confidentiality in mediation exists e.g. in the European Code of Conduct for Mediators, which regulates both in a brief manner in the two following sentences of its Point 4:

The mediator must keep confidential all information arising out of or in connection with the mediation, including the fact that the mediation is to take place or has taken place, unless compelled by law or grounds of public policy to disclose it. Any information disclosed in confidence to mediators by one of the parties must not be disclosed to the other parties without permission, unless compelled by law.

The internal (based on the "open communication" approach) and external dimensions of confidentiality are also addressed in the UNCITRAL Model Law: ${ }^{18}$

Article 8 (Disclosure of information)

When the conciliator receives information concerning the dispute from a party, the conciliator may disclose the substance of that information to any other party to the conciliation. However, when a party gives any information to

\footnotetext{
${ }^{15}$ Ibidem, p. 248.

${ }^{16}$ Mediators who prefer the "open communication" approach usually argue that a free flow of information and the principle that no secrets should be kept by the mediator are essential for building trust in mediation. The proponents of the alternative model indicate that it is more effective: the parties are more likely to disclose the information to a mediator if they assume that it will remain confidential, unless they expressly authorize a mediator to disclose it to the other party. See a detailed discussion on that issue in Alexander [1], pp. 249-250.

${ }^{17}$ See comments in Sect. 7.

${ }^{18}$ In Europe, similar regulation is included e.g. in Article 10 of the Slovenian Mediation in Civil and Commercial Matters Act (ZMCGZ). In turn, for example, the Italian Decree 28/2010, Article 9(2), is based "in-confidence" approach.
} 
the conciliator, subject to a specific condition that it be kept confidential, that information shall not be disclosed to any other party to the conciliation.

Article 9 (Confidentiality)

Unless otherwise agreed by the parties, all information relating to the conciliation proceedings shall be kept confidential, except where disclosure is required under the law or for the purposes of implementation or enforcement of a settlement agreement. (...)

The regulation of confidentiality in the EU Directive is in turn limited to the "insider/court" relation only.

Article 7 (Confidentiality of mediation)

1. Given that mediation is intended to take place in a manner which respects confidentiality, Member States shall ensure that, unless the parties agree otherwise, neither mediators nor those involved in the administration of the mediation process shall be compelled to give evidence in civil and commercial judicial proceedings or arbitration regarding information arising out of or in connection with a mediation process, except:

(a) where this is necessary for overriding considerations of public policy of the Member State concerned, in particular when required to ensure the protection of the best interests of children or to prevent harm to the physical or psychological integrity of a person; or

(b) where disclosure of the content of the agreement resulting from mediation is necessary in order to implement or enforce that agreement.

2. Nothing in paragraph 1 shall preclude Member States from enacting stricter measures to protect the confidentiality of mediation.

The Directive remains silent not only on the internal, but also on all other aspects of the external dimension, i.e. disclosures outside litigation or arbitration proceedings. All the above issues have been left to the discretion of the Member States.

The brevity of the Directive's norms on confidentiality is reflected by the fact that the Directive does not actually impose an express duty to keep information from the mediation confidential. However, such an obligation can be inferred-in relation to the mediator-by way of interpretation of the provisions of the Directive. ${ }^{19}$

\section{Who is obliged to respect confidentiality in mediation?}

Even if the mediation procedure is not public, a group of people may gain access to what is discussed therein. This group includes: parties, mediators, legal advisers, experts consulted, judges involved (in judicial or court-annexed mediation) as well as auxiliary staff of all these persons (secretarial staff, assistants, translators, ${ }^{20}$ etc.).

\footnotetext{
${ }^{19}$ Henke [11], p. 29.

${ }^{20}$ On the need to extend the safeguards concerning confidentiality of mediation communications to include such staff—see e.g. "Guide to Good Practice under the Hague Convention of 25 October 1980 on the Civil Aspects of International Child Abduction. Mediation", Hague Conference on Private International Law 2012, para. 77.
} 
Under the EU Directive, the group of individuals obliged to respect confidentiality is much narrower and encompasses only "mediators [and] those involved in the administration of the mediation process" (Article 7(1)). The parties to mediation are not (at least not expressly) bound by the confidentiality-related obligations under the Directive. ${ }^{21}$ Such regulatory policy raises significant doubts. The most relevant dangers for confidentiality do not originate from the mediator (in particular as a potential witness in judicial proceedings), but from the parties themselves. In most cases, they just do not need a mediator, but can act on their own, to introduce the information from the mediation process into subsequent litigation or arbitration in their pleadings or documentary evidence. ${ }^{22}$

The UNCITRAL Model Law adopts a much broader approach than the Directive. Not only does it encompass the parties to a mediation process among those obliged to respect confidentiality ("a party to the conciliation proceedings, the conciliator and any third person, including those involved in the administration of the conciliation proceedings"-Article 10(1)), but even lists them in the first place, before the mediator.

Many national mediation laws have followed the same direction. For example, in Bulgaria, the relevant obligation applies to all "participants in a mediation process". ${ }^{23}$ In the 2011 Croatian Mediation Law, while the core regulation in Article 14(1) and (2) is addressed to a mediator, the same rules "apply accordingly to the parties and other persons who have participated in mediation proceedings in any capacity" (Article 14(3)). However, it is not the case in all the Member States. In Poland, for example, explicit legal safeguards of confidentiality in mediation apply to the mediator only (Article 183[4] of the Civil Procedure Code).

\section{What information is protected against disclosure under the confidentiality principle?}

Confidentiality may extend to different communications and kinds of information within the mediation process, including e.g.: factual statements, concessions, offers and other information shared by parties in a joint session, information provided to the mediator in a private session or in a phone call or email, documents created or prepared for the purposes of mediation, the mediator's notes, the mediator's observations on the behavior and conduct of participants in mediation, or on the reasons for failure to reach agreement at mediation. ${ }^{24}$

The UNCITRAL Model Law, when stating the general obligation of confidentiality in Article 9 (Confidentiality), relates to "all information relating to the conciliation proceedings". In addition, with respect to the issue of inadmissibility of evidence

\footnotetext{
${ }^{21}$ Henke [11], p. 29. M. Marinari reported that a similar wording in the Article 9 of the Italian Decree 28/2010 caused concerns related to uncertainty as to whether it applies to the parties in the dispute Marinari [14].

${ }^{22}$ Eidenmüller, Prause [8], p. 2741.

${ }^{23}$ Article 7 (1).

${ }^{24}$ Reichert [19], p. 62.
} 
in subsequent litigation or arbitration, Article 10(1) lists, in a detailed manner, the following categories of communications:

(a) An invitation by a party to engage in conciliation proceedings or the fact that a party was willing to participate in conciliation proceedings;

(b) Views expressed or suggestions made by a party in the conciliation in respect of a possible settlement of the dispute;

(c) Statements or admissions made by a party in the course of the conciliation proceedings;

(d) Proposals made by the conciliator;

(e) The fact that a party had indicated its willingness to accept a proposal for settlement made by the conciliator;

(f) A document prepared solely for purposes of the conciliation proceedings.

A similar list had been envisaged in the draft EU Directive of $2004 .{ }^{25}$ Finally, however, the Directive's provisions were to a great degree shortened and watered down. Its confidentiality regulation, i.e. the evidentiary exclusion in Article 7(1) of the Directive, relates to the general category of "information arising out of or in connection with a mediation process". ${ }^{26}$ Most national mediation laws in the EU Member States also use broad terms such as "any and all data and information obtained in a mediation process" 27 or "die Tatsachen, die im Rahmen der Mediation anvertraut oder sonst bekannt wurden" 28 ), and avoid listing specific examples of communications protected under the mediation privilege.

Further, the Directive does not explicitly protect documentary evidence related to mediation. In several Member States its Article 7(1) (“(...) mediators (...) shall [not] be compelled to give evidence") has been implemented in the form of an evidentiary restriction related to hearing the mediator as a witness (testimonial evidence). ${ }^{29} \mathrm{Un}$ der the Italian Decree 28/2010, uncertainty about protection of documentary evidence has been referred to as a "troubling issue". 30

When regulating the scope of confidential information, policymakers need to take into account, inter alia, the two following premises. On the one hand, there is a need to cover the various means of storing and transferring information, as well as the different types of communications within the mediation process. This goal may be satisfied by the use of spacious legal formulas, like the ones referred to above. On the other hand, however, one should avoid the risk of creating an incentive that one party agrees to mediation only in order to block information and evidence in subsequent litigation and arbitration.

\footnotetext{
${ }^{25}$ Proposal for a Directive of the European Parliament and of the Council on certain aspects of mediation in civil and commercial matters \{SEC(2004) 1314\}, Brussels, 22.10.2004, COM(2004) 718 final, 2004/0251 (COD), Article 6.

${ }^{26}$ Subject to the exceptions presented in Sect. 7 below.

${ }^{27}$ Hungarian Act LV of 2002 on Mediation, Sect. 26.

${ }^{28}$ Austrian Zivilrechts-Mediations-Gesetz (ZivMediatG), Sect. 18.

${ }^{29}$ See detailed comments in Sect. 6.4.

${ }^{30}$ Marinari [14], p. 191.
} 
The UNCITRAL Model Law attempted to tackle the latter problem in Article 10(5):

Subject to the limitations of paragraph 1 of this article, evidence that is otherwise admissible in arbitral or judicial or similar proceedings does not become inadmissible as a consequence of having been used in a conciliation.

Both the Directive and most national mediation laws in the Member States ${ }^{31}$ are silent on the above issue.

\section{How confidentiality of mediation is protected?}

\subsection{General remarks}

The confidentiality duties may arise from different sources. So do the measures of protection and remedies. As noted above, the Directive provides only for a single mandatory measure, i.e. the evidentiary exclusion in Article 7(1), and grants the Member States the liberty to introduce stricter instruments of protection. A review of mediation regulations presents a wide array of alternative or additional solutions. It also leads to the conclusion that the standards of confidentiality protection in the EU Member States differ vastly. Lack of coherence and related uncertainty do not serve well to the promotion of cross-border mediation practice in Europe.

\subsection{Contract}

While the European standard set forth in the Directive is clearly insufficient, a contract (in particular a mediation agreement) has often been seen as a primary source of confidentiality duty and safeguards. This approach is reflected e.g. in the European Code of Conduct for Mediators (point 3.1), which reads as follows:

The mediator must in particular ensure that prior to commencement of the mediation the parties have understood and expressly agreed the terms and conditions of the mediation agreement including any applicable provisions relating to obligations of confidentiality on the mediator and on the parties.

However, contractual safeguards of confidentiality have their limits and drawbacks. Firstly, from the policymaking perspective, it is questionable whether a contractfocused model of protection is appropriate and sufficient, in particular in matters other than commercial or for those parties who act without the representation of a professional attorney. Secondly, contractual evidentiary exclusions may be ineffective vis-à-vis some public law regulations, such as state court procedures. For example, in most jurisdictions, a contractual confidentiality obligation will not give a mediator the privilege to refuse to testify and provide evidence in criminal proceedings. In all instances where criminal proceedings law holds that the state itself (acting e.g.

\footnotetext{
${ }^{31}$ However, for example, in Denmark, "information which is otherwise available to the public" is expressly exempted from the confidentiality principle_Danish Administration of Justice Act, Clause 277.
} 
through a public prosecutor), and not e.g. the injured party, must establish the facts of the case at hand, contractual arrangements inter partes are simply irrelevant. ${ }^{32}$

\subsection{Implied agreement}

In the jurisprudence of some countries the doctrine of "implied agreement" has been proposed. It comes into play when the parties had earlier failed to conclude an explicit mediation contract (or failed to cover all the relevant issues therein), and there are no statutory laws to fill the gap. According to this concept, by entering into a mediation process, the parties impliedly agree to accept its fundamental principles, including confidentiality. Thus they enter into an implied agreement on confidentiality.

\subsection{Evidence and submission restrictions in law}

The basic standard envisaged in Article 7(1) of the Directive has been implemented and developed in national mediation laws. ${ }^{33}$ They provide for different approaches to evidence restrictions (leading to the inadmissibility of certain evidentiary materials), such as the prohibition on calling a mediator to testify, right for witnesses (in particular mediators, legal advisers and other involved third parties) of refusal to testify in general or with respect to some specified subject matters.

In parallel to the mediation privilege, some other traditional evidentiary restrictions may come into play in the context of mediation in individual cases, such as legal professional privilege, privilege against self-incrimination, marital privilege, or public interest privilege. ${ }^{34}$ In common-law countries, confidentiality in mediation is protected by the "without prejudice" privilege, which was originally developed in relation to settlement negotiation. ${ }^{35}$

Similar to the evidentiary constraints discussed above are submission restrictions applicable to a party and/or its counsel. For example, under Polish law, revealing information about settlement proposals, mutual concessions, or other statements made in mediation to the court or an arbitration tribunal is ineffective, meaning that such information should not be taken into account when making a judgment (Article 183[4] $\S 3 \mathrm{CCP})$.

\footnotetext{
${ }^{32}$ This is the case e.g. in Germany-see Ch. Duve, Lessons learnt from the implementation of the EU Mediation Directive in Germany: the point of view of lawyers, Brussels 2011, www.europarl.europa.eu/ studies, p. 8.

${ }^{33}$ Its direct equivalent in the UNCITRAL Model Law may be identified in its Article 10(1): "A party to the conciliation proceedings, the conciliator and any third person, including those involved in the administration of the conciliation proceedings, shall not in arbitral, judicial or similar proceedings rely on, introduce as evidence or give testimony or evidence regarding (...)" and Article 10(3): "The disclosure of the information referred to in paragraph 1 of this article shall not be ordered by an arbitral tribunal, court or other competent governmental authority and, if such information is offered as evidence in contravention of paragraph 1 of this article, that evidence shall be treated as inadmissible".

${ }^{34}$ See e.g. Kirtley [13]; Miller [16].

${ }^{35}$ See e.g. Ehrhardt [6].
} 


\subsection{Damages and restraining orders}

Breach of confidentiality may also result in a claim for damages. In most cases it would be pursued under the general rules of civil liability, be it either a contract law claim or a tort law claim. A handful of mediation laws regulate such a remedy, in a specific manner, in their provisions. ${ }^{36}$ One can also apply for an injunction to restrain breach of confidence. ${ }^{37}$

\subsection{Administrative or disciplinary measures}

The nature of confidentiality obligations, and the consequences of mediators' professional malpractice, including various administrative or disciplinary measures, can vary according to the professional affiliation of the mediators, e.g. lawyer-mediators, notary-mediators or psychologist-mediators. ${ }^{38}$

For example, in Germany, in the absence of legislative provisions on confidentiality directly applicable to mediation, the laws that govern mediators' professional affiliation applied before 2012. Therefore it was indicated as an advantage to having a lawyer as a mediator that lawyers have a statutory confidentiality obligation. ${ }^{39}$ They are by law required to keep all information confidential that they were provided with in the course of their professional activities ( $\$ 43 \mathrm{a}$ II of the Federal Lawyer's Act, Bundesrechtsanwaltsordnung-BRAO). They also have the right to refuse to give evidence in civil ( $\$ 383$ I Nr. 6 ZPO) and criminal proceedings ( $\$ 53$ I Nr. 3 Strafprozessordnung-StPO).

Lack of coherence and uniform standards within the emerging mediators' profession have been (and still remain) a problem in several other Member States.

\subsection{Criminal sanctions}

In some countries ${ }^{40}$ the consequences of an unauthorized disclosure of information protected under mediation confidentiality amount to criminal sanctions. Probably, most wide-known example of such regulation comes from Austria, where §31 (1) of the Zivil-Mediations-Gesetz provides for imprisonment of up to 6 months for a breach of the confidentiality duty. ${ }^{41}$

While mediation laws in most countries do not provide for such harsh penalties, willful or negligent leaks of confidential information may potentially be subject to sanctions under the general rules. For example, under German criminal law, a misuse of private information entrusted in confidence can be a punishable offense under

\footnotetext{
${ }^{36}$ See e.g. the Belgian Code judiciaire, Article 1728(1).

${ }^{37}$ Eidenmuller [7], p. 28.

${ }^{38}$ Matthews [15].

${ }^{39}$ Ch. Duve, Lessons learnt..., p. 7.

${ }^{40}$ Penal sanctions for a mediator or an expert who disregard their duty of confidentiality are provided e.g. under Article 458 of the Code pénal in Belgium.

41 \$1(1) "Wer entgegen seiner Pflicht zur Verschwiegenheit und Vertraulichkeit (§18) Tatsachen offenbart oder verwertet und dadurch ein berechtigtes Interesse einer Person verletzt, ist vom Gericht mit einer Freiheitsstrafe bis zu sechs Monaten oder einer Geldstrafe bis zu 360 Tagessätzen zu bestrafen."
} 
$\S 203$ of the Criminal Code (Strafgesetzbuch-StGB). A criminal sanction may apply to anyone who has received said information while employed inter alia as: a professional psychologist, lawyer or tax accountant, or marriage or family counselor. If members of these professions work as mediators specifically because of their expertise (e.g. legal expertise for a lawyer, psychological expertise for a psychologist etc.), $\S 203$ StGB applies to them. ${ }^{42}$

\section{Exceptions to the confidentiality principle}

The integrity of the mediation process requires that confidentiality provisions do not provide safe-havens for participants' wrongdoing or injustice. ${ }^{43}$ The principle of confidentiality must not be absolute, and be subject to some exceptions. Their character and reasoning differ.

\subsection{Waiver}

Many national regulations follow the rule that confidentiality may be waived by a joint decision of the parties to mediation. This rule is prescribed, inter alia, in Article 7(1) of the Directive ("unless the parties agree otherwise"). In consequence, even if a mediator objects to giving evidence in subsequent juridical proceedings, but the parties agree that the mediator should testify, he or she has no grounds to refuse to give evidence under the Directive.

\subsection{Enforcement of a mediation settlement}

Likewise, there are a few controversies related to the exception that confidentiality must be relieved to the extent it is necessary to enforce a mediation settlement. ${ }^{44}$ For example, under the UNCITRAL Model Law, Article 10(3): “(...) [confidential] information may be disclosed or admitted in evidence (...) for the purposes of implementation or enforcement of a settlement agreement." The EU Directive, Article 7(2), identifies a similar exception "where disclosure of the content of the agreement resulting from mediation is necessary in order to implement or enforce that agreement." 45

\subsection{Public policy exception and duty to report}

The most problematic, but also most needed exception to the confidentiality principle relates to the overriding interest of public policy. Confidentiality must be weighed against the needs of public safety and security, and the protection of the most vital interests of individuals.

\footnotetext{
${ }^{42}$ Ch. Duve, Lessons learnt ..., p. 8, with references to legal writings in the field of criminal law.

${ }^{43}$ Alexander [1], p. 280.

${ }^{44}$ Deason [5].

${ }^{45}$ Similar regulations may be found e.g. in the Belgian Code judiciaire, Article 1728, or the Bulgarian Mediation Law, Article 7(3)(3).
} 
According to the EU Directive, Article 7(2), confidentiality is relieved "where this is necessary for overriding considerations of public policy of the Member State concerned, in particular when required to ensure the protection of the best interests of children or to prevent harm to the physical or psychological integrity of a person". ${ }^{46}$

Several EU Member States decided that the general public policy exception would be too vague and too broad, and its use could threaten the confidential nature of mediation. Thus they did not include it at all, or replaced it with other narrowed down exceptions. This group includes e.g. Belgium, ${ }^{47}$ Cyprus, ${ }^{48}$ Italy ${ }^{49}$ or Poland.

While finding a broader international consensus on acceptable exceptions to the confidentiality principle impossible, the UNCITRAL Model Law leaves them to individual states: "[confidential] information may be disclosed or admitted in evidence to the extent required under the law" (Article 10(3)).

\section{Conclusions}

Confidentiality is one of the fundamental tenets of mediation. It encourages the candid flow of information in frank and open discussions. It is almost a truism that the effectiveness of mediation depends on participation with openness and candor. ${ }^{50}$ Therefore the mediation practice needs the safeguards of confidentiality. They must be real and adequate. Human nature dictates that people talk to others despite obligations of confidentiality. More often than not breaches of confidentiality do not have significant consequences. However, when they do, adequate legal remedies should be available.

There may be something more than just a coincidence in the observation that in those jurisdictions where mediation practice is best developed, strict legal safeguards of confidentiality are in place. For example, California's mediation confidentiality provisions, codified in the California Evidence Code (CEC), are known for their strictness. Very few exceptions to confidentiality exist, and those that do are consistently narrowly construed. ${ }^{51}$

Meanwhile, the EU Directive provides for a minimum degree of compatibility and very basic standards. It addresses a single issue of the evidentiary restriction to forbid hearing a mediator as a witness in a potential subsequent litigation or arbitration. However, real dangers for confidentiality originate elsewhere. A number of relevant issues are left beyond the ambit of the Directive, such as disclosures outside the scope of litigation, duties of not only the mediator but also the parties and other participant to the mediation process, and available remedies in case of unauthorized disclosure.

\footnotetext{
${ }^{46}$ See e.g. the Bulgarian Mediation Law, Article 7(3)(1) and (2).

${ }^{47}$ Verougstraete [22].

${ }^{48}$ The 2011 Cyprus Mediation Bill, Sect. 26.

${ }^{49}$ Marinari [14].

${ }^{50}$ New South Wales Law Reform Commission, Alternative Dispute Resolution-Training and Accreditation of Mediators, Report No. 67, 1991, p. 63, http://www.lawreform.lawlink.nsw.gov.au/agdbasev7wr/ 1rc/documents/pdf/report_67.pdf.

${ }^{51}$ Peterson [17]. See also Callahan [4], p. 64. The pro-confidentiality approach has been confirmed by the Californian courts, for example in California Supreme Court's decision in Cassel v. Superior Court, 179 Cal. App. 4th 152.
} 
The legal regime is not strengthened by stricter protections arising from the UNCITRAL Model Law. The Model Law has been implemented in (or significantly influenced) just a handful of European countries. Therefore national mediation laws in Europe are currently developing at a different pace and in different directions, adopting different standards regarding confidentiality protection. Arguably, such problems could and should be remedied by more efforts towards harmonization.

In cross-border disputes, the legal situation is by definition complex. A clash of different standards resulting from the interplay of two or more legal systems, such as the laws of countries where the parties originate from, the law applicable to the subject matters dealt with in mediation, the law applicable to the mediation process itself etc., leads to lack of coherence, uncertainty and divergent, often incidental results. For example, in the event of an unauthorized disclosure to an outsider other than a court, such as a market competitor, the legal consequences of such actions would differ significantly among the EU Member States.

The need for a more coherent approach to regulating confidentiality in mediation was already expressed in the European Parliament Resolution of 13 September 2011 on the implementation of the directive on mediation in the Member States, its impact on mediation and its take up by the courts. ${ }^{52}$ Thus far, however, no initiative in this respect has been undertaken. If the problem is not remedied, we may soon find ourselves in a situation similar to the one which existed in the United States, when the Uniform Mediation Act was enacted in 2001. At that time, there were more than 300 state statutes throughout the US providing some form of protection of confidentiality. The UMA was an attempt to create some uniformity in this area.

Sooner or later the mediation practice in Europe may face similar problems. The need for further harmonization to establish higher standards and greater clarity is already apparent.

Open Access This article is distributed under the terms of the Creative Commons Attribution License which permits any use, distribution, and reproduction in any medium, provided the original author(s) and the source are credited.

\section{References}

1. Alexander, N.: International and Comparative Mediation: Legal Perspectives (Global Trends in Dispute). Kluwer Law International, Alphen aan den Rijn (2009)

2. Antaki, N.N.: Cultural diversity and ADR practices in the world. In: Goldsmith, J.-C., Ingen-Housz, A., Pointon, G.H. (eds.) ADR in Business: Practice and Issues Across Countries and Cultures, pp. 265-303. Kluwer Law International, Alphen aan den Rijn (2006)

\footnotetext{
${ }^{52}$ European Parliament resolution of 13 September 2011 on the implementation of the directive on mediation in the Member States, its impact on mediation and its take-up by the courts (2011/2026(INI)) (2013/C 51 E/03), P7_TA(2011)0361, Point 1: “(...)Observes that the requirement of confidentiality set out by the Directive already existed in certain Member States' domestic legislation: in Bulgaria, the Code of Civil Procedure states that mediators can refuse to testify about a dispute they have mediated; in France and Poland the laws governing civil mediation establish similar provisions; notes that, among the Member States, Italy adopts a rigorous approach to the confidentiality of mediation proceedings, whilst the Swedish mediation rules state that confidentiality is not automatic and require an agreement between the parties to that effect; considers that a more coherent approach seems to be needed."
} 
3. Brazil, W.: Protecting the confidentiality of settlement negotiations. Hastings Law J. 39, 955-1029 (1988)

4. Callahan, R.: Mediation confidentiality: for California litigants, why should mediation confidentiality be a function of the court in which the litigation is pending? Pepperdine Dispute Resolut. Law J. 12(1/2), 63-96 (2012)

5. Deason, E.E.: Enforcing mediated settlement agreements: contract law collides with confidentiality. UC Davis Law Rev. 35(1), 33-102 (2001)

6. Ehrhardt, Ch.W.: Confidentiality, privilege and rule 408: the protection of mediation proceedings in federal court. La. Low Rev. 60(1), 91-126 (1999)

7. Eidenmuller, H.: Vertrags- und Verfahrensrecht der Wirtschaftsmediation. Otto Schmidt Verlag, Cologne (2001)

8. Eidenmüller, H., Prause, M.: Die europäische Mediationsrichtlinie - Perspektiven für eine gesetzliche Regelung der Mediation in Deutschland. Neue Jurist. Wochenschr. 61(38), 2737-2742 (2008)

9. Goldberg, S.B., Sander, F.E.A., Rogers, N.H.: Dispute Resolution: Negotiation, Mediation, and Other Processes. Aspen Publishers, Gaithersburg (1999)

10. Green, E.D.: A heretical view of the mediation privilege. Ohio St. J. Disp. Resolut. 2(1), 1-36 (1986)

11. Henke, E.-M.: Confidentiality in the Model Law and the European Mediation Directive: a Comparison of Solutions Offered in the Mediation Directive and the Model Law on Conciliation with Examination of the Actual Situation in Selected Civil and Common Law Countries. GRIN Verlag, Munich (2012)

12. Hughes, S.H.: A closer look: the case for a mediation privilege has not been made. Disp. Resolut. Mag. Winter 5(2), 14 (1998)

13. Kirtley, A.: The mediation privilege's transition from theory to implementation: designing a mediation privilege standard to protect mediation participants, the process and the public interest. J. Disp. Resolut. 1, 1-54 (1995)

14. Marinari, M.: Italy. In: De Palo, G., Trevor, M.B. (eds.) EU Mediation Law and Practice, p. 191. Oxford University Press, Oxford (2012)

15. Matthews, R.J.: Do I have to say more? When mediation confidentiality clashes with the duty to report. Campbell Low Rev. 34(1), 205-227 (2011)

16. Miller, R.F.: Creating evidentiary privileges: an argument for the judicial approach. Conn. Low Rev. 31(2), 771 (1999)

17. Peterson, A.L.H.: When mediation confidentiality and substantive law clash: an inquiry into the impact of in re marriage of Kieturakis on California's confidentiality law. Pepperdine Disp. Resolut. Law J. 8(1), 199-219 (2008). Available at http://digitalcommons.pepperdine.edu/drlj/vol8/iss1/7

18. Reich, J.: A call for intellectual honesty: a response to the uniform mediation act's privilege against disclosure. J. Disp. Resolut. 2, 197-252 (2001)

19. Reichert, K.: Confidentiality in international mediation, dispute. Resolut. J. 59(4), 60 (2005)

20. Sekolec, J., Getty, M.: The UMA and the UNCITRAL model rule: an emerging consensus on mediation and conciliation. J. Disp. Resolut. 1, 175-196 (2003)

21. Ury, W.L.: The Third Side Why We Fight and How We Can Stop. Penguin Books, New York (2000)

22. Verougstraete, I.: Belgium. In: De Palo, G., Trevor, M.B. (eds.) EU Mediation Law and Practice, pp. 19-32. Oxford University Press, Oxford (2012) 